\title{
分子模块设计育种引领未来育种科技新方向 中国科学院战略性先导科技专项“分子模块设计育种创新体系”简介
}

\author{
李明 \\ 中国科学院遗传与发育生物学研究所科研计划处, 北京 100101 \\ E-mail: liming@genetics.ac.cn
}

收稿日期: 2015-03-05; 接受日期: 2015-04-16; 网络版发表日期: 2015-05-25 doi: 10.1360/N052015-00114

育种技术经历了以 20 世纪 30 年代杂交玉米 $(Z e a$ mays)、60 年代矮秆水稻( Oryza sativa) 和小麦(Triticum aestivum) 的绿色革命、80 年代转基因抗虫棉 (Gossypium hirsutum) 等重大科技成果为代表的传统 育种、遗传育种和分子育种的 3 次变革, 每一次变革 都为解决粮食短缺问题和促进育种科技跨越发展做 出了巨大贡献. 然而这些科技成果的取得仍难以满 足人类对粮食日益增长的需求, 据联合国粮食及农 业组织 (Food and Agriculture Organization of the United Nations, FAO)预测, 2050 年粮食需求将会翻番, 这就需要作物产量保持年增长 $2.4 \%$ 以上, 因此迫切 需要育种科技的创新.

我国是一个农业大国，水稻、小麦、鱼等主要农 产品的持续稳定生产对保障我国农业可持续发展具 有重大的现实和战略意义. 多年来, 育种家们培育了 大量高产优质品种, 为解决 13 亿人的吃饭问题做出 了巨大贡献. 但是, 近年来主要农产品的产量和品质 都处于徘徊不前的局面, 难以满足我国粮食安全的需 求. 常规育种面临育种周期长、效率低、遗传背景狭 窄等瓶颈问题, 而转基因技术主要针对少数单基因控 制的性状改良，难以培育针对复杂性状改良的突破性 新品种. 因此, 提高育种科技水平, 发展新一代育种 理论和技术体系是现代种业发展的迫切需求.

基因组学、系统生物学、计算生物学和合成生物 学等学科发展和兴起为作物产量、品质和耐逆性等重
要农艺性状的解析和动物繁殖力、抗病性以及品质等 重要经济性状的遗传改良带来了新的机遇, 也为生 物育种技术创新奠定了科学基础. 科学家研究发现, 多数重要农艺(经济)性状是由多基因控制的复杂性 状，而且其基因调控网络常呈现“模块化”的特性. 分 子模块是控制复杂性状的主效基因或多基因网络并 可进行遗传操作的功能单元, 系统负责相关模块功 能的发挥与最终目标性状的形成. 发掘和解析控制 农业生物复杂性状形成的分子模块并将它们有效地 耦合，通过实践验证最终创制设计型新品种，将成为 实现品种升级换代的创新性技术体系.

针对国家重大需求和科技创新的迫切需要，中 国科学院率先组织创新团队. 该团队以中国科学院 遗传与发育生物学研究所薛勇彪研究员为首席科学 家, 以中国科学院上海生命科学研究院副院长韩斌 院士、水生生物研究所桂建芳院士、植物研究所种康 研究员为领衔科学家, 以中国农业部副部长、中国农 业科学院院长李家洋院士为学术委员会主任, 吸纳 中国科学院 10 余家优势育种理论与技术单位的核心 力量, 在对育种科学进行了战略前瞻性研究与探索 预研的基础上，于 2013 年 11 月正式启动中国科学院 “分子模块设计育种创新体系”A类战略性先导科技 专项 (以下简称“专项”). 专项依托单位为中国科学院 遗传与发育生物学研究所, 参加单位包括中国科学 院植物研究所、中国科学院上海生命科学研究院、中

引用格式: 李明. 分子模块设计育种引领未来育种科技新方向一一国科学院战略性先导科技专项“分子模块设计育种创新体系”简介. 中国科学: 生命科学, 2015, 45: 591-592

Li M. Designer breeding by molecular modules will navigate future breeding technology. SCIENTIA SINICA Vitae, 2015, 45: 591-592, doi $10.1360 / \mathrm{N} 052015-00114$ 
国科学院水生生物研究所等 15 家单位.

专项针对我国粮食安全和战略性新兴产业发展 的重大需求, 以水稻为主, 以小麦、鲤 (Cyprinus carpio) 等为辅, 利用野生种、农家品种、主栽(养)品 种以及优良种质资源, 综合运用基因组学、计算生物 学、系统生物学、合成生物学的方法, 解析高产、稳 产、优质、高效等重要农艺(经济)性状的分子模块, 揭 示分子模块系统解析和耦合规律, 优化多模块组装 的品种设计的最佳策略, 培育水稻、鲤等产量显著提 高的初级模块设计新品系(种), 创建从“分子模块” 到“设计型品种”的现代生物技术育种创新研究体系 (图 1), 为保障我国粮食安全提供核心战略支撑.

专项 5 年总体目标是解析并获得高产、稳产、优 质和高效分子模块 16 20 个和主效分子模块系统 12 15 个, 建立模块耦合组装的理论和应用模型, 实 现高产、稳产、优质、高效模块的高效组装, 培育产 量提高 $8 \%$ 以上的水稻、鲤等初级分子模块设计型新 品系(种)10 15 个.
专项十年总体目标是阐明控制复杂性状多分子 模块组合 20 30 个, 通过多模块的耦合与遗传操作, 实现复杂性状的模块组装，培育产量提高 $10 \%$ 15\%, 养分效率提高 5\% 10\%的分子设计型新品种(系) $30 \sim 40$ 个, 建立第 1 代分子设计育种理论体系.

专项长期目标是全面解析控制复杂性状的分子 调控网络, 通过多模块计算模拟和定向设计育种技 术实现动植物复杂性状的设计、耦合和组装, 完善分 子设计育种理论和技术体系, 育成产量提高 $15 \%$ 以 上的高产、优质、稳产和高效的分子设计型品种 10 15 个.

民以食为天. 习近平总书记 2013 年底在山东考 察时强调: “手中有粮, 心中不慌. 保障粮食安全对中 国来说是永恒的课题，任何时候都不能放松”. 专项 的启动和顺利实施, 标志着我国主要作物育种开始 了“模块设计”育种的新时代，这对于保障我国农业 可持续发展和粮食安全有着非常重要的战略意义.

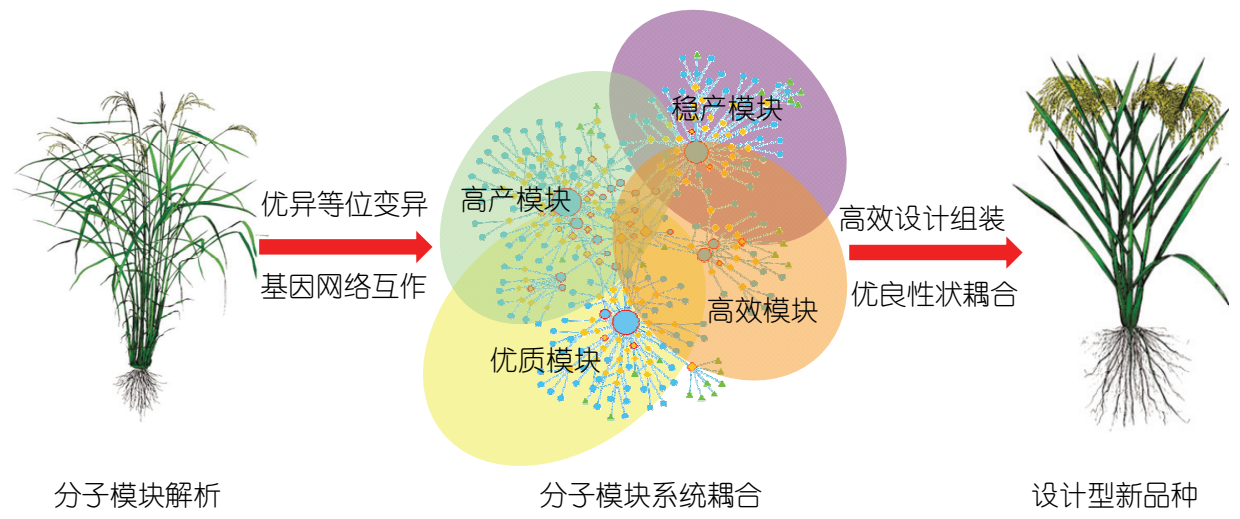

图 1 分子模块设计育种创新研究体系 